\title{
Foreign and Spatial Spillovers in the European Electricity Sector
}

\author{
Chiara F. Del Bo
}

\begin{abstract}
Productivity determinants of the urban domestic electricity sector in a crosssection of EU countries are examined to unveil the existence of two forms of spillover effects: those from foreign firms (foreign spillovers) and those related to spatial interactions (spatial spillovers). The empirical analysis also assesses the importance of industrial disaggregation in the context of the ongoing policy reform process at the EU level, aimed at creating a single competitive market for electricity.

Results suggest that domestic productivity is influenced by agglomeration economies, and in particular scale economies; that both foreign and spatial spillovers are present; and that the overall implication of foreign presence and domestic firms' ownership is differentiated across the generation and distribution segments of the electricity sector. The latter result highlights the importance of properly defining a firm's relevant market, from the perspective of policy makers and firm managers alike.
\end{abstract}

Keywords: Productivity Spillovers; Foreign Presence; Spatial Issues; Electricity Sector

\section{Productivity in the European Electricity Sector}

A widespread, European Union (EU)-wide, reform process is ongoing in the electricity sector, due to its strategic nature to households and the industrial sector alike. With the aim of increasing competition, a set of policy actions, namely liberalization, unbundling, integration and privatization have been set forth by the EU, as summarized by a set of directives (for an overview see Del Bo, 2013a), aimed at creating a single European market for electricity, starting from the generation segment and gradually also expanding to distribution. ${ }^{1}$ An important feature of the current situation is that, while the overall goal of a single, competitive and efficient electricity sector is shared by all EU countries, the actual composition of national markets varies greatly. In fact, as a result of this common reform process, national markets with monopolistic features, mostly dominated by previously state-owned firms, have been replaced by a wide array of market structures, with the presence of domestic and foreign firms, both privately- and

* Assistant Professor of Public Finance, University of Milan (chiara.delbo@unimi.it)

Edited by: ISTEI - University of Milan-Bicocca

ISSN: 1593-0319

Del Bo Chiara F. (2014) Foreign and Spatial Spillovers in the European Electricity Sector, Symphonya. Emerging Issues in Management (symphonya.unimib.it), n. 1, pp. 52 - 65.

http://dx.doi.org/10.4468/2014.1.04delbo 
publicly-owned, local or global in nature. With respect to the latter issue, the local dimension of the relevant market for firms in the electricity sector, especially in the distribution segment, is however still relevant, as documented, e.g., by Filippini, 1998 and Saplacan, 2008. Focusing on internationalization, firms have started extending their activities outside domestic borders, both within and outside Europe, thus increasing the share of foreign presence across EU countries (Kolk et al., 2013).

Iberdrola, a leading Spanish multinational utility company, has recently been awarded the title of "Energy Company of the Year" in the context of the 8th annual Platts Global Energy Awards, Underlying motivations for this award include: "The judges' decisions reflect the genuinely global nature of the energy industry today and the way in which renewable energy is coming to the fore. Iberdrola is a true leader in environmental stewardship, as well as being an exceptionally wellrun business",2.

Considering instead public versus private ownership, while several countries have gone in the direction of privatization (Haney and Pollitt, 2013 for the electricity sector; Gnecchi, 2004 for an overview of the public utilities sector in Italy), others are still characterized by widespread public presence, especially at the municipal level (e.g. Germany), suggesting the need for evaluating the relationship between firms' ownership and productivity.

From the perspective of a (local) public planner, the reform process is successful if it achieves the goal of more efficient and ultimately productive firms, operating in a competitive environment without the possibility of rent extraction and noncompetitive pricing strategies. This could also positively influence social welfare, thus providing benefits to end users (households and firms in other sectors). Existing research on the direct impact of the reform process on consumers' welfare, however, suggests caution in expecting automatic benefits from single steps in isolation (Fiorio, Florio 2013; Willner, Grönblom 2013). These authors stress the importance of regulation, competition and the overall institutional arrangements that may have direct and indirect impacts on consumers, also via productivity improvements at the firm level.

With this framework in mind, a natural research question is to identify the drivers of domestic productivity in the electricity sector, taking into account the presence of spatial and industrial effects and explicitly focusing on the aspects which might have been affected by the EU-wide reform process. The productivity of the urban domestic electricity sector in a cross-section of EU countries is thus considered to examine whether there are spillover effects (both from foreign presence and in terms of spatial interactions) and if industrial disaggregation matters (which might also be implicitly linked to spatial and foreign spillovers), while considering the outcomes of the reform process. The choice of the urban scale is motivated by the importance of the local dimension of electricity markets in the EU and thus to better identify potential spatial spillover effects, which manifest themselves at the regional and urban levels (Andersson, Lööf, 2011). This level of spatial disaggregation is also motivated by a global transformation trend in urban 
structures, which reflects the interplay between sectoral and functional specialization (Duranton, Puga 2005; He, Xiao 2011).

Empirical results might be useful to both policy makers and firm managers. A significant association between foreign presence and domestic productivity can be interpreted as an indication of an underlying relationship between the reform process at the EU level and firm level performance, thus providing guidance for further policy actions. Similar conclusions can be reached by considering the implications of competition both from within and outside a firm's sector of operation. The significant association of industrial disaggregation, spatial interactions, and foreign presence, on the one hand, with domestic productivity, on the other, may also be used by firms' managers to better define and stir firm level policies, fully taking into account the importance of sectoral and international issues.

This paper is related to three main strands of literature examining: productivity spillovers from foreign presence, spatial spillovers at the regional level and the determinants of productivity in the electricity sector. The main findings of the first strand are based on firm level data in manufacturing industries and evaluate the existence and sign of productivity spillovers to domestic firms from foreign presence, computed as the share of foreign firms over the total in a given country, usually in terms of operating revenues or profits. Aitken and Harrison (1999) and Girma and Gorg (2004) focus on horizontal spillovers, i.e. spillovers arising from foreign firms operating in the same sector as the considered domestic firms while Javorcik (2004) examines vertical spillovers, arising from foreign firms operating in upstream (forward vertical spillovers) or downstream (backward vertical spillovers) sectors. Evidence is in favor of positive vertical spillovers arising from backward linkages (Javorcik 2004) while the sign of horizontal spillovers depends on idiosyncratic characteristics of the host country and of domestic firms. Spatial spillovers are instead mainly analyzed at the regional level, and papers in this area help model and interpret spatial issues in the data generating process. Moreno et al. (2005) focus on knowledge creation and diffusion and estimate a regional knowledge production function with patent data, unveiling the existence of significant spatial spillover effects from neighboring regions. Ertur and Koch (2007) provide a theoretical modelling framework of spillover effects in a growth model with technological interdependence. In the empirical application, spatial growth spillovers are found to be positive and significant as documented also by Basile (2008). Productivity determinants in the electricity sector have been studied both in relation to internal and technological features (Jaraite, De Maria 2012; Ramos-Real et al. 2009; Barros, Peypoch 2007; Abbott 2005) and to the importance of the reform processes that have taken place in EU and non-EU countries (Pollitt 2009; Jamasb 2005; Hogan 2002). For an overview of the former, see Erdogdu (2011).

\section{Empirical Model and Data}

Blending insights from previous literature on productivity determinants in the electricity sector and considering features of the reform process aimed at creating a single, competitive, EU single electricity market, the following conceptual model is 
the starting point for the subsequent empirical analysis. Figure 1 exemplifies the main drivers of domestic productivity at the urban level, within the overarching issue of industrial aggregation. Aggregate domestic productivity is directly influenced by features that are internal to the market, related in particular to the predominant ownership type (public or private; Hjalmarsson, Veiderpass 1992), size (cumulated total assets of domestic firms; Abbott 2005) and firms' financial structure (leverage; Nucci et al. 2005), and external to the market. External determinants include spatial interactions with other domestic urban markets (productivity levels of electricity markets in other neighboring cities, i.e. spatial spillovers) and the presence of foreign firms (foreign spillovers). Industrial factors influence productivity indirectly, since they are implicitly linked to all the other determinants, both internal and external.

This conceptualization formalizes the importance of both scale economies, internal to the firm and captured by size, and agglomeration economies (Song Lee et al. 2010), which capture the external benefits of the agglomeration of production activities in urban areas. The model also allows accounting for both MAR- and Jacobs- type agglomeration economies (Marshall 1890; Arrow 1962; Romer 1986; Jacobs 1969). With respect to the former, co-location with other firms in the same sector should enhance learning economies and this is captured by the spillovers from foreign presence within the same region and spatial spillovers from domestic productivity in neighboring regions in the aggregate electricity sector (351, NACE Rev. 2 classification). Jacob-type externalities are considered instead to originate from firms in other sectors within the same region, in this case in the generation and distribution segments (3511 and 3513, respectively, NACE Rev. 2 classification), where the association with firms in the downstream and upstream segments is explicitly considered.

Figure 1: Conceptual Model

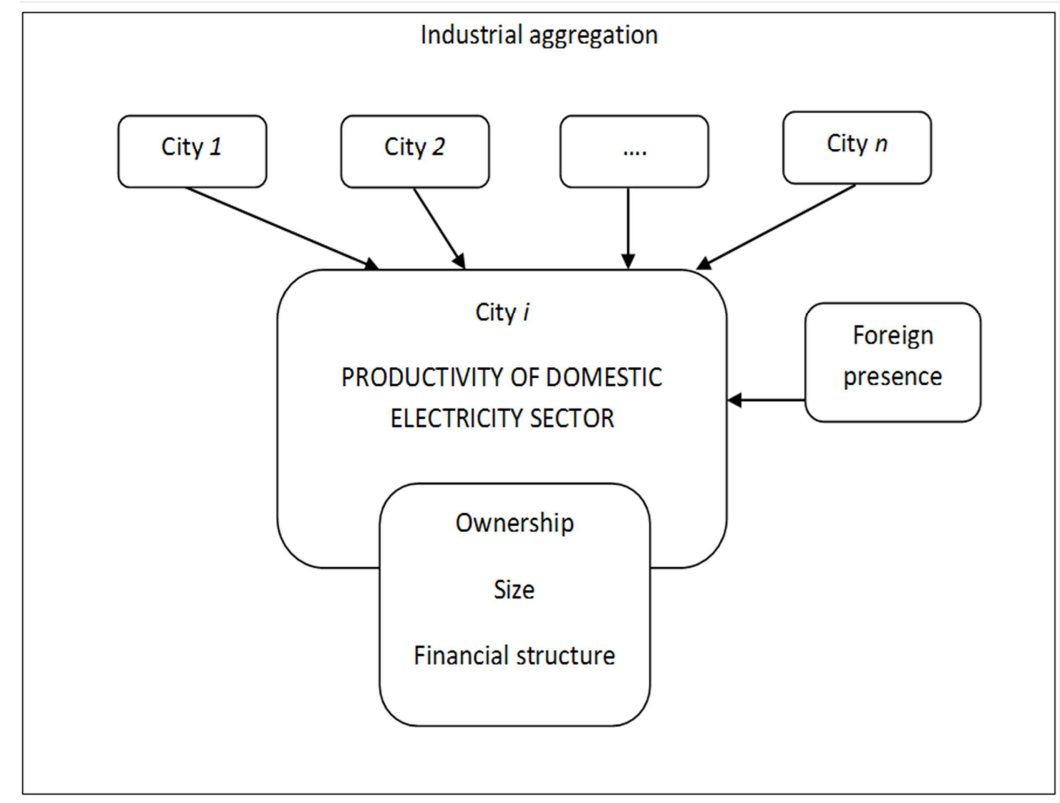


Firm level data is taken from the Amadeus database (Bureau Van Dijk), which provides yearly balance-sheet data for European private and public firms, as reported to the national registers. Data used in the present analysis is a cross section of firms operating in EU countries in 2009.

The empirical analysis is carried out in three steps. First, firm level productivity for domestic firms is obtained by estimating the following production function between 2002 and 2009 by means of the Levinsohn and Petrin (2003) methodology, with lower case letters referring to natural logarithms and subscript $i$ referring to firms and $t$ to time:

$$
\text { Eq. } 1 y_{i t}=\beta_{0}+\beta_{k} k_{i t}+\beta_{l} l_{i t}+\beta_{m} m_{i t}+a_{i t}+u_{i t}
$$

In Eq. 1, $y$ are operating revenues, $k$ are tangible fixed assets, $l$ employees and $m$ material costs, a proxy for intermediate inputs used in the production process. The term $u$ represents the true, i.i.d. error term, while $a$ represents unobserved productivity which can be expressed as a function of observable capital and intermediate inputs. Ordinary Least Square estimation of Eq. 1 may return biased estimated coefficients if unobserved productivity shocks are correlated to choices of inputs. To overcome this problem we resort to the Levinsohn and Petrin methodology which relies on semi-parametric techniques and uses firms' intermediate inputs as a proxy for unobserved (by the firm) productivity shocks. The firm-level measure of TFP is obtained as the residual from estimation of the production function in Eq. 1, and is made up of firm-level unobserved productivity and unexpected deviations from the mean. The urban-level aggregate TFP measure is obtained by averaging the values of TFP for firms located in each city included in the sample.

Table 1 provides some aggregate descriptive statistics in terms of size and productivity levels for firms in the aggregate electricity sector (Table 1, Column 1), in the generation segment (Table 1, Column 2) and in distribution (Table 1, Column 3 ). On average, firms in generation, with respect to those operating in distribution, are characterized by a higher value of total assets, slightly less employees, lower tangible fixed assets and lower levels of productivity. These figures highlight the underlying technological differences of the two segments of the electricity industry, with large, capitalized firms active in generation, and firms with relevant fixed capital (possibly related to the medium voltage distribution network), but with relatively fewer total assets, in distribution.

Table 1: Firm-Level Descriptive Statistics

\begin{tabular}{cccc} 
& Electricity & Generation & Distribution \\
\hline Total Assets & 565,428 & 666,186 & 359,805 \\
Employees & 321 & 296 & 350 \\
Tangible Fixed Assets & 236,851 & 198,575 & 250,842 \\
TFP & 5.98 & 5.43 & 6.32 \\
Observations & 907 & 551 & 288 \\
\hline \hline
\end{tabular}


Productivity spillovers from foreign presence are then computed as in Del Bo (2013) considering the share of operating revenues of foreign firms over the total at the regional (NUTS2) ${ }^{3}$ level.

$\square$ The importance of competitors, suppliers and customers within the same region is corroborated by the number of orders from suppliers located in the region Lombardia for A2A in 2012: 71.8\% of orders are from within A2A's same region, $26.3 \%$ from other Italian regions, $1.7 \%$ from within the EU and only $0.1 \%$ from outside the EU. ${ }^{4}$

Information on firm level productivity, estimated as explained above, total assets $(T A)$, public ownership $(P O)$ and leverage (Lev, computed as total liabilities over total assets) are then aggregated at the urban level to compute aggregate domestic productivity $(T F P)$ for the electricity sector (351, NACE Rev. 2 three-digit classification) and the generation (3511, NACE Rev.2 four-digit classification) and distribution (3513, NACE Rev. 2 four-digit classification) segments. Finally, urban productivity determinants are examined by estimating the following specifications for a cross section of 570 EU cities in 2009, with subscript $c$ referring to cities:

$$
\begin{aligned}
& \text { Eq. } 2 T_{F P}=\beta_{0}+\beta_{1} T A+\beta_{2} L e v+\beta_{3} P O+\beta_{4} H s p i l l+\mu_{c} \\
& \text { Eq. } 3 T F P_{c}=\beta_{0}+\beta_{1} T A+\beta_{2} L e v+\beta_{3} P O+\beta_{4} H s p i l l+\beta_{5} V s p i l l+\mu_{c}
\end{aligned}
$$

where Hspill represents horizontal spillovers from foreign firms located in the same sector (at both the three- or four-digit level) and Vspill represents forward/backward vertical spillovers from firms located in the upstream/downstream sector.

Equations 2 and 3 are estimated first with Ordinary Least Squares (OLS) and residuals are examined to verify the presence of residual spatial autocorrelation. If present, spatial models are estimated with Maximum Likelihood (ML) and the appropriate spatial model (Spatial Error or Spatial Lag) is chosen by means of Lagrange Multiplier (LM) tests.

\section{Results}

\subsection{Aggregate Electricity Sector}

When considering the urban domestic aggregate electricity sector (NACE Rev. 2 351), signs of spatial autocorrelation in the residuals are found using OLS estimates (Columns 1 and 2, Table 2), ${ }^{5}$ suggesting the estimation of a spatial model. The appropriate specification according to Lagrange Multiplier tests ${ }^{6}$ is the Spatial Error model, suggesting the existence of a spatially clustered feature that influences the productivity levels for each city and its neighbors that is omitted from the empirical specification (Columns 3 and 4, Table 1). The main results that emerge from inspection of the estimated coefficients are related to both internal and external productivity determinants. Firm size, measured by total assets, is positively and significantly related to domestic productivity, as is public ownership, both in the OLS and Spatial Error specification. Leverage, instead, does not appear to be 
relevant in either model. Cities characterized by large domestic firms, and by relatively widespread public ownership are, on average, found to have higher levels of productivity. Moving on to external factors, foreign presence in the aggregate electricity sector, as measured by horizontal spillovers, does not appear to be related to urban domestic productivity, in OLS nor in the Spatial Error model. Spatial spillovers per se are instead positive and significant, suggesting the existence of spatially clustered disturbances, possibly related to omitted variables.

The next step is to consider the role of industrial aggregation, and examine urban productivity determinants in the two segments of generation and distribution (Section 3.2).

Table 2: Urban Domestic Productivity Determinants: The Aggregate Electricity Sector

\begin{tabular}{ccccc} 
& \multicolumn{2}{c}{ OLS } & $(3)$ & $(4)$ \\
\cline { 2 - 5 } Dep. Var. TFP & $(1)$ & $(2)$ & $0.528^{* * *}$ & $0.527^{* * *}$ \\
Total Assets & $0.526^{* * *}$ & $0.525^{* * *}$ & 0.000 & 0.000 \\
Leverage & 0.000 & 0.000 & 0.24 & 0.24 \\
& 0.25 & 0.24 & 0.233 & 0.235 \\
Public Ownership & 0.217 & 0.225 & $0.443^{*}$ & $0.435^{*}$ \\
Horizontal Spillover & $0.465^{* *}$ & $0.455^{* *}$ & 0.051 & 0.056 \\
& 0.028 & 0.033 & & -0.17 \\
Lambda & & -0.20 & 0.257 \\
& & 0.607 & $0.496 * *$ & $0.490^{* *}$ \\
Constant & $\mathrm{n} . \mathrm{a}$. & $\mathrm{n} . \mathrm{a}$ & 0.021 & 0.023 \\
& & & 0.04 & 0.05 \\
Observations & 0.05 & 0.05 & 0.116 & 0.089 \\
$\mathrm{R}^{2} /$ Log-likelihood & 0.147 & 0.240 & 570 & 570 \\
\hline \hline
\end{tabular}

Notes: robust p-values in italics. *** Significant at the $1 \%$ level, $* *$ significant at the $5 \%$ level and * significant at the $10 \%$ level.

\subsection{The Role of Sectoral Disaggregation}

The general picture provided above in the aggregate electricity sector could be misleading as the two segments of generation (Table 3) and distribution (Table 4) are intrinsically different, in terms of both technological and commercial features. Starting from generation, the first observation is related to the modelling of spatial issues. While OLS results are biased because of spatial autocorrelation, ${ }^{7}$ the preferred model is the Spatial Lag, ${ }^{8}$ which suggests that the level of productivity in city $i$ is directly influenced by productivity values in neighboring cities, with high (low) productivity urban generation markets clustered near other high (low) productivity markets. The spatial features of productivity levels in the electricity generation segment are thus quite distinct from what can be gauged by considering the aggregate electricity sector (Section 3.1), suggesting that, both from a firm's manager and policymaker's perspective, clearly defining the appropriate sectoral 
scale of analysis is crucial. Analyzing in greater detail productivity determinants, size and public ownership are still important covariates and are both positively associated to urban productivity in both the a-spatial and spatial specification.

Considering the case of France, of the domestic firms for which there is information in the dataset, the two state-owned firms (CIE Nationale Du Rhon and Electricité de France) exhibit the highest estimated productivity levels compared to their private counterparts, in an unconditional analysis. Focusing on other dimensions of efficiency, CIE Nationale Du Rhon is the first French producer of electricity from renewable resources, ${ }^{9}$ while Electricité de France has a value for the Ebitda Margin of $21.31 \%,{ }^{10}$ against an average of the top 25 utilities in 2012 of $17.9 \%{ }^{11}$

Leverage is once again not significant, suggesting that the financial structure of firms operating in the urban generation market is not related to the overall productivity levels. Interestingly, when considering foreign presence, both horizontal and vertical backward spillovers are never significant. This finding, read together with the insignificance of the spatial parameter $\rho$, suggests that, in the generation segment of the electricity sector, spillover effects do not appear to be relevant in explaining variations of productivity. A potential explanation of this result is related to the timing of the EU reform process which has been first applied in the generation segment. The absence of relevant spillover effects, both spatial and industrial, from foreign presence, may be an indication of an open and competitive sector, in which productivity is a function of mainly internal factors.

Table 3: Urban Domestic Productivity Determinants: The Electricity Generation Segment

\begin{tabular}{|c|c|c|c|c|c|c|}
\hline \multirow[b]{2}{*}{ Dep. Var. TFP } & \multicolumn{3}{|c|}{ OLS } & \multicolumn{3}{|c|}{ Spatial Lag } \\
\hline & (1) & (2) & (3) & (4) & (5) & $(6)$ \\
\hline \multirow[t]{2}{*}{ Total Assets } & $0.486^{* * * *}$ & $0.485^{* * *}$ & $0.485^{* * *}$ & $0.484 * * *$ & $0.483 * * *$ & $0.483 * * *$ \\
\hline & 0.000 & 0.000 & 0.000 & 0.000 & 0.000 & 0.000 \\
\hline \multirow[t]{2}{*}{ Leverage } & 0.14 & 0.14 & 0.14 & 0.16 & 0.16 & 0.16 \\
\hline & 0.535 & 0.538 & 0.541 & 0.497 & 0.499 & 0.501 \\
\hline \multirow[t]{2}{*}{ Public Ownership } & $0.543^{*}$ & $0.539^{*}$ & $0.537^{*}$ & $0.577 *$ & $0.574^{*}$ & $0.572 *$ \\
\hline & 0.077 & 0.079 & 0.082 & 0.059 & 0.061 & 0.062 \\
\hline \multirow{2}{*}{$\begin{array}{l}\text { Horizontal } \\
\text { Spillover }\end{array}$} & & -0.04 & -0.03 & & -0.04 & -0.04 \\
\hline & & 0.306 & 0.364 & & 0.273 & 0.324 \\
\hline \multirow{2}{*}{$\begin{array}{l}\text { Vertical Demand } \\
\text { Spillover }\end{array}$} & & & -0.02 & & & -0.02 \\
\hline & & & 0.549 & & & 0.565 \\
\hline \multirow[t]{2}{*}{ Rho } & & & & 0.17 & 0.17 & 0.17 \\
\hline & & & & 0.157 & 0.153 & 0.153 \\
\hline \multirow[t]{2}{*}{ Constant } & 0.01 & 0.02 & 0.02 & -0.18 & -0.17 & -0.17 \\
\hline & 0.684 & 0.572 & 0.542 & 0.205 & 0.212 & 0.218 \\
\hline Observations & 332 & 332 & 332 & 332 & 332 & 332 \\
\hline
\end{tabular}




\begin{tabular}{lllllll} 
R2/Log-likelihood & 0.91 & 0.91 & 0.91 & -95 & -94 & -94 \\
\hline \hline
\end{tabular}

Notes: robust p-values in italics. *** Significant at the $1 \%$ level, ** significant at the $5 \%$ level and * significant at the $10 \%$ level.

The role of spillovers is instead important when considering the distribution segment (Table 4). Inspection of results in the OLS specification again suggests the estimation of a Spatial Error model, ${ }^{12}$ as in the aggregate electricity sector analysis (Table 2), although the spatial parameter $\lambda$ is not statistically significant at the usual conventional levels. Starting from internal factors, the size of firms located in the city is relevant, and the positive estimated coefficient is relatively high with respect to other variables and to the estimation results in generation (Table 3) and the aggregate sector (Table 2). The domestic productivity of urban distribution markets is thus significantly related to the available total assets of firms operating within its boundaries, mainly due to the importance of the medium voltage distribution network which allows the dispatch of electricity from producers to end users. On the contrary, public ownership does not seem to matter, differently from the situation in the aggregate sector and in generation, as leverage, which remains insignificant as before. Focusing on spillovers form foreign presence, domestic productivity is positively related to foreign firms both in the same segment (horizontal spillovers) and in the upstream generation segment (vertical forward spillovers). When explicitly modelling spatial issues, only vertical spillovers remain statistically significant.

Considering as an example the German region of NordrheinWestfalen, the domestic and public firm Dortmunder Energie- und Wasserversorgung, operating in distribution, may be in relation, via workers' mobility, supply contracts, or by other forms of commercial and technical exchanges, with the foreign firms operating in generation within the same region, such as, for example, Centrica Energie GMBH (a British multinational) and Knapsack Power GMBH (a division of Statkraft, a Norwegian state-owned electricity company).

The overall message, for domestic urban distribution markets, suggests that foreign presence is associated to higher productivity levels, possibly because of the transfer of more efficient productive and managerial practices from foreign to domestic firms.

Table 4: Urban Domestic Productivity Determinants: The Electricity Distribution Segment

\begin{tabular}{ccccccc} 
& \multicolumn{3}{c}{ OLS } & \multicolumn{3}{c}{ Spatial Error } \\
\cline { 2 - 7 } Dep. Var. TFP & $(1)$ & $(2)$ & $(3)$ & $(4)$ & $(5)$ & $(6)$ \\
\hline \multirow{2}{*}{ Total assets } & $0.633^{* * *}$ & $0.633^{* * *}$ & $0.635^{* * *}$ & $0.633^{* * *}$ & $0.634^{* * *}$ & $0.635^{* * *}$ \\
& 0.000 & 0.000 & 0.000 & 0.000 & 0.000 & 0.000 \\
Leverage & $0.503^{*}$ & $0.509^{*}$ & $0.515^{*}$ & $0.511^{*}$ & $0.514^{*}$ & $0.517^{*}$ \\
& 0.082 & 0.080 & 0.077 & 0.072 & 0.071 & 0.069
\end{tabular}




\begin{tabular}{ccccccc} 
Public ownership & -0.26 & -0.25 & -0.25 & -0.24 & -0.24 & -0.24 \\
& 0.418 & 0.425 & 0.420 & 0.447 & 0.448 & 0.4432 \\
$\begin{array}{l}\text { Horizontal } \\
\text { spillover }\end{array}$ & & $0.088^{*}$ & $0.076^{*}$ & & 0.07 & 0.07 \\
& & 0.066 & 0.079 & & 0.139 & 0.145 \\
$\begin{array}{c}\text { Vertical supply } \\
\text { spillover }\end{array}$ & & & $0.039^{*}$ & & & $0.035^{*}$ \\
& & & 0.064 & & & 0.085 \\
lambda & n.a. & n.a. & n.a. & 0.36 & 0.32 & 0.28 \\
& & & & 0.112 & 0.174 & 0.264 \\
Constant & 0.02 & 0.02 & 0.01 & 0.02 & 0.02 & 0.01 \\
& 0.355 & 0.475 & 0.747 & 0.336 & 0.446 & 0.708 \\
$\begin{array}{c}\text { Observations } \\
\text { R2/Log- }\end{array}$ & 243 & 243 & 243 & 243 & 243 & 243 \\
likelihood & 0.98 & 0.98 & 0.98 & 123 & 123 & 123 \\
\hline \hline
\end{tabular}

Notes: robust p-values in italics. *** Significant at the $1 \%$ level, ** significant at the $5 \%$ level and * significant at the $10 \%$ level.

\section{Discussion and Implications}

Having in mind the research question set out in the first section, urban domestic productivity in the electricity sector is indeed related to spillover effects, both in a spatial perspective and in terms of foreign presence, and industrial aggregation is crucial in shaping this relationship, as the behavior of the aggregate and disaggregated sectors differs considerably.

Starting from the two disaggregated segments, in generation there seems to be a lack of spillover effects at play, while direct internal features (mainly ownership and size, both with a positive estimated coefficient) are relevant in explaining productivity variations at the urban level. In distribution, instead, industrial spillovers are an important covariate of domestic productivity and spatial issues, indicating dependence in the error term, are present. Results also suggest that there might be a link between the spatial structure of the data and the role of industrial spillovers, and more research is needed to better understand the interplay between these two factors. Differently from generation, where the association with productivity is positive, public ownership is statistically unrelated to domestic productivity in distribution, while size is even more important in explaining variation in productivity levels, again with a positive sign.

Taken together these results suggest, in the first place, the relevance of the level of industrial aggregation at which the analysis is carried out. The two segments are intrinsically different in terms of technology, production processes, cost structures and evolution of the reform process. Starting from the latter, generation has been historically the first segment of the electricity industry to be affected by liberalization, unbundling, integration and privatization and the absence of residual spillover effects in explaining productivity levels at the urban scale could be read as a success in achieving competitiveness in the sector. In terms of technical features, 
generation differs significantly from distribution and productivity might be more heavily related to production technologies (in terms of, for example, generation technologies such as nuclear, carbon, gas, hydropower, wind, solar etc.). In distribution, instead, the reform process started at a later phase, and local markets may still have features of local monopolies, suggesting that the dynamic process is still ongoing and that the sector has not yet reached a steady state. The underlying spatial element could also be linked more specifically to the medium-voltage network, as suggested by the higher coefficient related to firms' total assets.

These considerations are however partially obscured when the empirical analysis focuses on the aggregate electricity sector. Here there is evidence of spatial issues, mainly driven by the distribution segment. In fact, both distribution and electricity in general are described by the same spatial model, the Spatial Error, which suggests that other spatially clustered features, not yet included in the empirical specification, might be relevant. With respect to the link between domestic productivity and foreign presence, there is a lack of a clear and identifiable spillover effect in the aggregate sector. Once again, this suggests that analyzing the implications for productivity of specific features, in particular related to the steps of the reform process, at different scales of industrial aggregation may significantly blur results. The relationship between foreign presence, which can be seen as the outcome of the integration of national markets towards a single EU-wide electricity market, and productivity, appears in fact to be substantially different in the two segments of generation and distribution and turns out not statistically significant when examining the aggregate electricity sector. Analogous considerations can be put forward to the implications of public ownership, another outcome of the privatization step of the reform process.

From a policy maker's perspective, this suggests that an evaluation of the implications and potential impact of the reform process of the electricity sector in terms of domestic productivity levels should be carried out by taking appropriately into account spatial issues at the relevant industrial scale. Potential direct or indirect effects on consumers' welfare, not only firm productivity levels analyzed here, could also be influenced by similar dynamics and should be factored in when assessing policy outcomes. From a firm's manager perspective, recognizing the interplay between industrial and spatial spillovers is relevant when defining the boundaries, both geographic and sectoral, of the firm's reference market. Competition effects and productivity spillovers are related to the electricity subsector or segment considered, suggesting that defining with precision the firm's primary activity and target market is crucial if the benefits of the reformed EU electricity market can be fully appropriated by firms.

\section{Bibliography}

Abbott Malcolm (2005) Determining Levels of Productivity and Efficiency in the Electricity Industry, The Electricity Journal, vol. 18 n.9, pp. 62-72.

http://dx.doi.org/10.1016/j.tej.2005.08.004

Aitken Brian J. Harrison Ann E. (1999) Do Domestic Firms Benefit from Direct Foreign Investment? Evidence from Venezuela, American Economic Review, vol. 89 n.3, pp. 605-618.

http://dx.doi.org/10.1257/aer.89.3.605 
Andersson Martin, Lööf Hans (2011) Agglomeration and Productivity: Evidence from Firm Level Data, The Annals of Regional Science, vol. 46 n. 3, pp. 601-20.

http://dx.doi.org/10.1007/s00168-009-0352-1

Arrow Kenneth (1962) Economic Welfare and the Allocation of Resources for Invention', in R. Nelson (ed.), The Rate and Direction of Inventive Activity, Princeton, NJ, Princeton University Press.

Barros Carlos P., Peypoch Nicolas (2007) The Determinants of Cost Efficiency of Hydroelectric Generating Plants: A Random Frontier Approach, Energy Policy, vol. 35 n. 9, pp. 463-4470. http://dx.doi.org/10.1016/j.enpol.2007.03.019

Basile Roberto (2008) Regional Economic Growth in Europe: A Semiparametric Spatial Dependence Approach, Papers in Regional Science, vol. 87 n.4, pp. 527-544.

http://dx.doi.org/10.1111/j.1435-5957.2008.00175.x

Del Bo Chiara F. (2013) Fdi Spillovers at Different Levels of Spatial and Industrial Disaggregation: Evidence From The Electricity Sector. Energy Policy, vol. 61, pp. 1490-1502. http://dx.doi.org/10.1016/j.enpol.2013.06.119

Del Bo Chiara F. (2013a) Productivity in electricity generation: The Role of Firm Ownership and Regional Institutional Quality, International Review of Applied Economics, vol. 27 n.2, pp. 237-264. http://dx.doi.org/10.1080/02692171.2012.734792

Duranton Gilles, Puga Diego (2005) From Sectoral to Functional Urban Specialization. Journal of Urban Economics, vol. 57 n. 2, pp. 343-370.

http://dx.doi.org/10.1016/i.jue.2004.12.002

Erdogdu Erkan (2011) What Happened to Efficiency in the Electricity Industries after Reforms? Energy Policy, vol. 39, pp. 6551-6560.

http://dx.doi.org/10.1016/j.enpol.2011.07.059

Ertur Cem, Koch Wilfried (2007) Growth, Technological Interdependence and Spatial Externalities: Theory and Evidence. Journal of Applied Econometrics, vol. 22 n. 6, pp. 1033-1062.

http://dx.doi.org/10.1002/jae.963

Filippini Massimo (1998) Are Municipal Electricity Distribution Utilities Natural Monopolies? Annals of Public and Cooperative Economics, vol. 69 n.2, pp. 157-174.

http://dx.doi.org/10.1111/1467-8292.00077

Fiorio Carlo V., Florio Massimo (2013) Electricity Prices and Public Ownership: Evidence from the EU15 over thirty years. Energy Economics, vol. 39, pp. 222-232.

http://dx.doi.org/10.1016/j.eneco.2013.05.005

Girma Sourafel, Gorg Holger (2004) Outsourcing, Foreign Ownership, and Productivity: Evidence from UK Establishment-level Data. Review of International Economics, vol. 12 n. 5, pp.817-832. http://dx.doi.org/10.1111/j.1467-9396.2004.00483.x

Gnecchi Flavio (2004) Relations between Local Authorities and Public Utilities Companies, Symphonya. Emerging Issue in Management (symphonya.unimib.it), n.1, pp. 58-68.

http://dx.doi.org/10.4468/2004.1.06gnecchi

Haney Aoife B., Pollitt Michael G. (2013) New Models of Public Ownership in Energy. International Review of Applied Economics, vol. 27 n. 2, pp. 174-192.

http://dx.doi.org/10.1080/02692171.2012.734790

He Canfei, Xiao Xiaojun (2011) Geography of Multinational Corporations and Functional Specialization in Chinese Cities, Symphonya. Emerging Issues in Management (symphnya.unimib.it), n.1, pp. 29-40.

http://dx.doi.org/10.4468/2011.1.04he.xiao

Hjalmarsson Lennart, Veiderpass Ann (1992) Productivity in Swedish Electricity Retail Distribution. The Scandinavian Journal of Economics, vol. 94, pp. S193-S205.

http://dx.doi.org/10.2307/3440259 
Hogan William W. (2002) Electricity Market Restructuring: Reforms of Reforms. Journal of Regulatory Economics, vol. 21 n. 1, pp. 103-132.

http://dx.doi.org/10.1023/A:1013682825693

Jacobs, Jane (1969) The economy of cities. Random House, NewYork

Jamasb Tooraj (2005). Electricity Sector Reform in Developing Countries: A Survey of Empirical Evidence on Determinants and Performance. Vol. 3549. World Bank.

Jaraitė Jurate, De Maria Corrado (2012) Efficiency, Productivity and Environmental Policy: A Case Study of Power Generation in the EU. Energy Economics, vol. 34 n. 5, pp. 1557-1568.

http://dx.doi.org/10.1016/j.eneco.2011.11.017

Javorcik Beata (2004) Does Foreign Direct Investment Increase the Productivity of Domestic Firms? In Search of Spillovers through Backward Linkages. The American Economic Review, vol. 94 n. 3, pp. 605-627.

http://dx.doi.org/10.1257/0002828041464605

Kolk Ans, Lindeque Johan, Van den Buuse Daniel (2013) Regionalization Strategies of European Union Electric Utilities. British Journal of Management, pp. 1467-8551.

Levinsohn James, Petrin Amil (2003) Estimating Production Functions Using Inputs to Control for Unobservables. Review of Economic Studies, vol. 70, pp. 317-341.

http://dx.doi.org/10.1111/1467-937X.00246

Marshall Alfred (1898) Principles of Economics. MacMillan, London

Moreno Rosina, Paci Raffaele, Usai Stefano (2005) Spatial Spillovers and Innovation Activity in European Regions. Environment and Planning A. 37(10): 1793-181.

http://dx.doi.org/10.1068/a37341

Nucci Francesco, Pozzolo Albert, Schivardi Francesco (2005) Is Firm's Productivity Related to its Financial Structure? Evidence from Microeconomic Data. Rivista di politica economica, vol. $95 \mathrm{n}$. 1, pp. 269-90.

Pollitt Michael G. (2009) Evaluating the Evidence on Electricity Reform: Lessons for the South East Europe (SEE) market. Utilities Policy, vol. 17 n. 1, pp. 13-23.

http://dx.doi.org/10.1016/j.jup.2008.02.006

Ramos-Real Francisco J., Tovar Beatriz, Iootty Mariana, de Almeida Edmar F., Pinto Helder Q. (2009) The Evolution and Main Determinants of Productivity in Brazilian Electricity Distribution 1998-2005: An Empirical Analysis. Energy Economics, vol. 31 n. 2, pp. 298-305.

http://dx.doi.org/10.1016/j.eneco.2008.11.002

Romer Paul (1986) Increasing Returns and Long-run Growth. Journal of Political Economy, vol. 94, pp.1002-1037.

http://dx.doi.org/10.2307/1833190

Song Lee B., Jang Soomyung, Hong Sung H. (2010) Marshall's Scale Economies and Jacobs' Externality in Korea: the Role of Age, Size and the Legal Form of Organisation of Establishments. Urban Studies, vol. 47, pp. 3131-3156.

http://dx.doi.org/10.1177/0042098009359953

Willner Johan, Grönblom Sonja (2013) Reforming a Network Industry: Consequences for Cost Efficiency and Welfare. International Review of Applied Economics, vol. 27 n. 2, pp. 265-284.

http://dx.doi.org/10.1080/02692171.2012.734789

\section{Notes}

\footnotetext{
${ }^{1}$ The transmission segment, which includes the high voltage network, is regulated separately and characterized by a limited number of firms, operating mainly at the domestic level and frequently state-owned, and is therefore not included in the analysis.

${ }^{2} \mathrm{http}$ ://www.prnewswire.com/news-releases/platts-global-energy-awards-hail-spanish-firmiberdrola-56576312.html, accesses on November 29, 2013.
} 


\footnotetext{
${ }^{3}$ Nomenclature of territorial units for statistics http://epp.eurostat.ec.europa.eu/portal/page/portal/nuts_nomenclature/introduction

${ }^{4}$ Source: http://bilancio.a2a.eu/en/2012/sustainability/socialresponsibility/suppliers/suppliers.html

${ }^{5}$ Moran's I of 3.83 and 4.01, significant at the $1 \%$ and 5\% level, respectively for the Spatial Error and Spatial Lag.

6 Robust LM test of 18.44 , significant at the $1 \%$ level for the Spatial Error $(12.99$, significant at the $1 \%$ level for the Spatial Lag).

${ }^{7}$ Moran's I of 2.47 and -0.42 , with p-values of 0.11 and 1.32 , respectively for the Spatial Lag and Spatial Error.

${ }^{8}$ Robust LM test of 4.17, significant at the 5\% level for the Spatial Lag (2.25, not significant for the Spatial Error).

${ }^{9}$ Source: http://www.cnr.tm.fr/energie.aspx

${ }^{10}$ Source: http://investing.businessweek.com/research/stocks/financials/ratios.asp?ticker=EDF:FP, accessed on November 27, 2013.

${ }^{11}$ Standard's and Poor, 2013.

${ }^{12}$ Moran's I of 1.918 and 4.01, significant at the $10 \%$ level and not significant, respectively for the Spatial Error and Spatial Lag. Robust LM test of 3.651, significant at the $10 \%$ level for the Spatial Error (2.45, not significant for the Spatial Lag).
} 